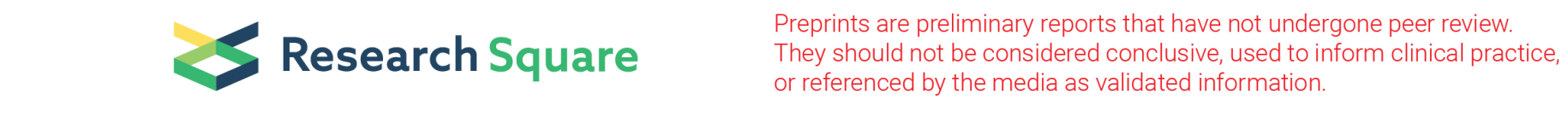

\title{
Bee Venom Acupuncture Therapy Ameliorates \\ Neuroinflammatory Alterations in a Pilocarpine-Induced Epilepticus Model
}

\author{
Abeer Mohamed Abd El-Hameed \\ King Saud University \\ Abdelaziz S. A. Abuelsaad ( $\square$ elsaad1@yahoo.com ) \\ Faculty of Science https://orcid.org/0000-0001-8244-9124 \\ Abdelwahab Khalil \\ Beni Suef University Faculty of Science
}

\section{Research Article}

Keywords: Epilepsy, Pilocarpine, Bee venom, inflammation, Cytokines, Neurotransmitters, oxidative stress

Posted Date: March 9th, 2021

DOI: https://doi.org/10.21203/rs.3.rs-217682/v1

License: (a) This work is licensed under a Creative Commons Attribution 4.0 International License. Read Full License 


\section{Abstract}

Background: Bee venom (BV) is applied in different traditional medicinal therapies and is used worldwide to prevent and treat many acute and chronic diseases. Epilepsy has various neurological effects, e.g., epileptogenic insults; thus, it is considered a life-threatening condition. Seizures and their effects add to the burden of epilepsy because they can have health effects including residual disability and even premature mortality. The use of antiinflammatory drugs to treat epilepsy is controversial; therefore, the alternative nonchemical apitherapy benefits of BV were evaluated in the present study by assessing neuroinflammatory changes in a pilocarpine-induced epilepticus model.

Methods: Levels of electrolytes, neurotransmitters, and mRNA expression for some gate channels were determined. Moreover, ELISA assays were conducted to detect pro- and anti-inflammatory cytokines, whereas RT-PCR was performed to assess mRNA expression of Foxp3 and CTLA-4.

Results: BV ameliorated the interruption in electrolytes and ions through voltage- and ligand-gated ion channels, and it limited neuronal excitability via rapid repolarization of action potentials. In addition, BV inhibited the high expression of proinflammatory cytokines.

Conclusions: Acupuncture with BV was effective in preventing some of the deleterious consequences of epileptogenesis associated with high levels of glutamate and DOPA in the hippocampus. BV ameliorates changes in the expression of voltage-gated channels, rebalances blood electrolytes and neurotransmitters, and modulates the levels of pro- and antiinflammatory cytokines. Thus, BV could reduce the progression of epileptogenesis as a cotherapy with other antiepileptic drugs.

\section{Introduction}

Epilepsy is a collection of diverse disorders that together affect approximately $1 \%$ of the general population. It affects people of all ages and is one the most prevalent chronic diseases of the central nervous system. About $80 \%$ of the 50 million people with epilepsy worldwide live in low- and middle-income countries. When adequately diagnosed and treated, an estimated $70 \%$ of epileptic patients will be seizure free. In low-income countries, however, about $75 \%$ of patients do not get the care they require and this figure can rise to $90 \%$ in certain countries (Who, 2020).

Over two decades ago, Shin and Mcnamara (1994) reported that antiepileptic drugs (AEDs) can regulate seizures in many patients and cure some patients; however, for the majority of epilepsies, there is no effective prophylactic protocol. Therefore, most AEDs only treat symptoms and are largely ineffective. Epileptic seizures are the primary symptom of epilepsy; these are repeated paroxysmal events marked by stereotyped behavioral changes that represent the neuronal pathways involved in the epileptic phase (Beghi et al., 2019). Diagnosing seizures and epilepsy is challenging, especially in low-income countries where socioeconomic and cultural limitations are barriers to disease detection and acceptance (Newton and Garcia, 2012). Many AEDs cannot prevent epileptogenesis without being used in combination with polytherapy. If seizures and epilepsy cannot be controlled after two drug trials, the epilepsy may be defined as drug-resistant epilepsy (Park et al., 2019).

To date, pharmacologic strategies to mitigate or prevent

epileptogenesis in humans-most notably after head injury-

have proven to be ineffective

To date, pharmacologic strategies to mitigate or prevent

epileptogenesis in humans-most notably after head injury-

have proven to be ineffective

Page 2/19 
Recent data has confirmed that many AEDs designed to ameliorate or downregulate epileptogenesis are not sufficiently effective (Löscher and Brandt, 2010) despite the noticeable neuroprotective effects of many such medications. The failure of these drugs may arise from several factors, e.g., species differences, inappropriate timing of intervention, focus on nonessential molecular targets, differential genetic susceptibility, and perhaps the long-term neurotoxicity of the drugs (Kobow et al., 2012).

As stated in a review by Abd El-Hameed et al. (2020), alternative medicines are gradually being introduced from Asian traditional medicine into western countries. Apitherapy is one such traditional medicine based on the use of various products of Apis mellifera (the European honeybee) including raw honey, propolis, pollen, royal jelly, beeswax, and venom (Stuhlmeier (2007). One example, bee venom (BV) therapy, which was developed in the 1950s and 1960s, has been used in wound healing and has the potential to treat many diseases and conditions such as asthma, rheumatoid arthritis, multiple sclerosis, polyneuritis, neuralgia, malaria, and epilepsy. In addition to reporting that all hive products have positive healing effects on wounds and burns, in a review by Trumbeckaite et al. (2015), various studies confirmed the antibacterial, antifungal, antiinflammatory, antiproliferative, and anticancer properties of honey products. In traditional medicine, BV is commonly used to cure immune-related diseases.

The venom of social insects such wasps, bees, and ants is used as a chemical weapon for protecting the individual or colony; extremely low concentrations of venom can incapacitate attackers in minutes (Krell, 1996). BV therapy (also known as apitherapy) was practiced in ancient Egyptian, Greek, and Chinese civilizations to treat epilepsy. BV of $A$. mellifera contains about $88 \%$ water and $0.1 \mu \mathrm{g}$ of dry venom (Nawaz et al., 2019). In one sting, about $50-140 \mu \mathrm{g}$ of venom is released by the bee. Various researchers have reported that dry venom is chemically composed of a complex mixture of active peptides (e.g., melittin), enzymes [e.g., phospholipase $\mathrm{A}_{2}$ (PLA2), hyaluronidase, and acid phosphatase], and biogenic amines (e.g., vasoactive amines and histamine) (Krishna et al., 2011). Verma et al. (2013) reported that melittin is the main active and hydrophobic peptide of $A$. mellifera venom and represents $50 \%-60 \%$ of the total chemical constituents. Over a series of apitherapy sessions representing adjusted dose-dependent venom immunotherapy, $A$. mellifera BV can cure patients from relapsed systemic anaphylactic reactions (Aust et al., 2010).

Melittin in BV has lytic activity if it is inserted into the phospholipid bilayer of the cell membrane (Cruciani et al., 1991). In addition to $P L A_{2}$ in $B V$ having a potent inflammatory activator; it is involved in various biological pathways including synthesis of arachidonic acid metabolites (Nair et al., 1993), and, as another active constituent of BV, apamin acts not only as a potent neurotoxin Stuhlmeier (2007) but also as a blocker of $\mathrm{K}^{+}$channels (Modzelewska et al., 2003).

For some neuroinflammatory diseases, drugs from venomous sources have been suggested as effective alternative treatments. Many previous studies have demonstrated the properties of the active constituents of BV; however, the present study examines the changes in neurotransmitter expression and the balance of both blood electrolytes and inflammatory biomarker levels after a therapeutic acupuncture treatment with BV in a pilocarpine-induced epilepticus model.

\section{Materials And Methods}

\subsection{Animals}

White thirty-two adult male Sprague Dawley rats (150-180 g) were obtained from the animal house of the National Research Institute, Doki, Giza, Egypt. Animals were housed in individual metabolic cages in a controlled environment $\left(23 \pm 1^{\circ} \mathrm{C}\right.$; humidity, $55 \pm 5 \%$ ) under a 12-h light/dark cycle. Food and water were available ad libitum under Ethical approval agreement.

\subsection{Drug, Chemicals and Bee Venom:}

Pilocarpine hydrochloride (99\%) (PILO) was purchased from Acros Organics (New Jersey, USA). In addition, methylscopolamine, diazepam and chloral hydrate were purchased from Nanjing Chemical Reagent Co., Ltd. (Nanjing, China). Depakine Chrono ${ }^{\circledR} 500 \mathrm{mg}$, Sanofi Aventis CO. Concerning purified honeybee (Apis mellifera) venom (BV) used in the 
present study was kindly provided from Egyptian Holding Company for Biological Products and Vaccines (VACSERA $\left.{ }^{\circledR}\right)$, Cairo, Egypt. BV was collected using a specialized collector without damaging the honeybee by an established electric shock method. BV was dissolved in distilled water and centrifuged at $12,000 \times \mathrm{g}$ for $10 \mathrm{~min}$ to remove insoluble materials. It was provided as a lyophilized product $(1 \mathrm{mg})$ and used in modified.

\subsection{Induction of Epilepsy and Animal grouping:}

Epilepsy was experimentally induced according to the method of Turski et al. (1989) and Abdel-Reheim (2009). Prior to treatment with $300 \mathrm{mg} / \mathrm{kg}$ of pilocarpine hydrochloride injection, the experimental rats were intraperitoneally injected with methylscopolamine $(1 \mathrm{mg} / \mathrm{kg})$ for $30 \mathrm{~min}$. Then, animal's behavior was evaluated as indicative of seizure activity was assessed according to certain criteria. These criteria for successful modeling: epileptic seizure symptoms (sluggishness, salivation, tremors, convulsions, etc.). Such behaviors were observed in model rats for $120 \mathrm{~min}$ after the administration of pilocarpine hydrochloride; while, rats in the control group behaved normally. When generalized seizure activity was continuously observed without normal behavior during each episode, the rats were considered suffer from seizure episodes. When the rats continuously suffered from seizure episodes for $1 \mathrm{~h}$, and the attacks occurred every 2-5 minutes. Seizures were terminated with diazepam (4 mg/kg, i.p.) delivered every 20 minutes as needed. Control rats were treated with the same protocol, except that phosphate buffered saline (PBS, $\mathrm{pH} 7.4 ; 0.2 \mathrm{ml} / \mathrm{rat}$ ) was injected instead of pilocarpine, followed, $1 \mathrm{~h}$ later, by diazepam.

Generally, thirty two adult male rats (150-180 g) were used in the present experiment. They were divide into five groups (eight rats/group) as follows: (1). Control group (C) received only standard diet, free access to sterile water and orally fed with (PBS, $\mathrm{pH} 7.4 ; 0.2 \mathrm{ml} / \mathrm{rat}$ ) using intragastric intubation at intervals parallel to the treated groups. (2). Positive epileptic group, epileptic control "EP group" was treatment with 300 mg pilocarpine hydrochloride/Kg. b.wt of rats. (3). Depakine®-treated epileptic group (EP_DK group): this group was injected with $300 \mathrm{mg} / \mathrm{kg}$ of pilocarpine hydrochloride injection as described previously, and then orally fed with 500mg Depakine ${ }^{\circledR} / \mathrm{Kg}$. b.wt of rats, dissolved in PBS (pH 7.4; $0.2 \mathrm{ml} / \mathrm{rat}$ ). Depakine® inoculation was performed twice/week for four consecutive weeks, using intragastric intubation at intervals parallel to other groups for four consecutive weeks. (4). Bee venom-treated epileptic group (EP_BV group): It was injected with $300 \mathrm{mg} / \mathrm{kg}$ of pilocarpine hydrochloride injection as described previously, and then injected intradermal (i.d.) with $10 \mu \mathrm{g} /$ animal once every 3 days for four consecutive weeks of pure BV dissolved in PBS (pH 7.4) according to a modified dose of Kim (1997); Koyama et al. (2000) and Ncbi (2020).

\subsection{Blood; Tissue Sampling and Biochemical Measurements:}

At the end of the experiment, rats were euthanized and sacrificed according to ethical committee of Beni-Suef University, BeniSuef, Egypt. Blood was immediately collected into a sterile vacutainer tube and allowed to coagulate for plasma or sera preparation by centrifugation at $3500 \mathrm{xg}$ for $15 \mathrm{~min}$, transferred into sterilized tubes and stored at $-20^{\circ} \mathrm{C}$ till used for analysis of various biochemical and immunological parameters. Briefly, blood samples were collected and harvested in two parts within $30 \mathrm{~min}$ at $37^{\circ} \mathrm{C}$ from EDTA-anticoagulated and EDTA-free samples. Sera samples were separated for electrolytes. The hippocampus was sliced from the brain on ice containing plates for determination of electrolytes and neurotransmitters. Briefly, parts of hippocampus tissue were homogenized in cooled PBS (pH 7.4) using Potter-Elvehjem homogenizer (Braun, Melsungen, Germany) with a loose-fitting Teflon pestle at $1000 \mathrm{~g}$ with eight up and-down strokes. After filtration, the homogenate was centrifuged at $600 \mathrm{x} g$ for $10 \mathrm{~min}$ at $4^{\circ} \mathrm{C}$ in a Beckman TJ-6 centrifuge (Beckman Instruments; Munich, Germany). Clear supernatant was kept in $-80 \mathrm{C}^{0}$ till evaluation of many investigations. Total protein (/gm tissue) was estimated in the supernatant (Bradford, 1976). Some slices of brain tissues were kept in sterilized Eppendorf tubes at $-70^{\circ} \mathrm{C}$ until they were used for RNA extraction and RT-PCR analysis.

Neurotransmitters were performed according to the purchased manufacture guide. MyBioSource Co. assay kits were used for quantitative detection of L- dihydroxyphenyalanine (L-DOPA; $\mu \mathrm{g} / \mathrm{ml})$; epinephrine $(\mathrm{ng} / \mathrm{ml})$; Norepinephrine $(\mathrm{pg} / \mathrm{ml})$; glutamate $(\mu \mathrm{g} / \mathrm{ml})$ and gamma-aminobutyric acid (GABA, pg/ml) using kits with catalogue numbers (MBS9357024, MBS031232, 
MBS269993, MBS047402 and MBS269152, respectively). Acetylcholinesterase (U/L) activity was performed according to the instruction manual of QuantiChrom ${ }^{\mathrm{TM}}$ Assay Kit (Cat. No: DACE-100). According to the instruction manual of MyBioSource; concentration of electrolytes $(\mathrm{mMol} / \mathrm{L})$ in either serum or brain homogenate tissue e.g. sodium $\left(\mathrm{Na}^{+}\right)$, potassium $\left(\mathrm{K}^{+}\right)$. In addition, calcium $\left(\mathrm{Ca}^{+2}\right)$ and chloride $\left(\mathrm{Cl}^{-}\right)$levels were determined according to the quantitative colorimetric instruction manual of QuantiChrom ${ }^{\text {TM }}$ assay. Levels of different cytokines e.g. IL-6; IL-10; IL-17; TNF-a, and TGF- $\beta$ (pg/mg protein tissues) were estimated by using ELISA Kit purchased from My Bio-source according to the manufacturer's protocol in triplicates.

\subsection{RNA isolation and qRT-PCR for Pro and anti-inflammatory cytokines:}

All gate receptors e.g. SCN1A ( $\mathrm{Na}^{+}$channel); Kcnj2 ( $\mathrm{K}^{+}$channel); CACNA1S ( $\mathrm{Ca}^{2+}$ channel); CLCN2 (GABA receptor); NMDA (Glutamate receptor); and T regulatory cell markers e.g. FOXP3 and CTLA4; were estimated by quantitative Real Time PCR. Analysis using SYBR Green I was performed using an applied BioSystem with software version 3.1 (StepOne ${ }^{\text {TM }}$, USA). The qPCR assay with sets target primer sequence at annealing temperature at $60^{\circ} \mathrm{C}$ for one min. Denaturation temperature at 95 ${ }^{\circ} \mathrm{C}$ for one min and extension temp at $72^{\circ} \mathrm{C}$ for one min (in one cycle) repeated for 40 cycles. PCR (RT-PCR) using rat specific primers listed in Table (1) as follows:

\begin{tabular}{|c|c|c|}
\hline Item & Primer & \\
\hline $\begin{array}{l}\text { SCN1A } \\
\left(\mathrm{Na}^{+} \text {channel }\right)\end{array}$ & F;5-TCATGGCACAGTTCCTGTATC-3 & R;5-GCAGTAGGCAATTAGCAGCAA-3 \\
\hline $\begin{array}{l}\text { Kcnj2 (Kir2.1) } \\
\left(\mathrm{K}^{+} \text {channel) }\right.\end{array}$ & F;5-GCAAACTCTGCTTGATGTGG-3 & R;5-TCATACAAAGGGCTGTCTTCG-3 \\
\hline $\begin{array}{l}\text { CACNA1S }\left(\mathrm{Ca}_{\mathrm{v}} 1.1\right) \\
\left(\mathrm{Ca}^{2+} \text { channel }\right)\end{array}$ & F;5-GACATAATTCCCGCTGCCTG-3 & R;5-GTTTCCATTCTTCACCCGCC-3 \\
\hline $\begin{array}{l}\text { CLCN2 } \\
\text { (GABA-receptor) }\end{array}$ & F;5-CACTGGATAACAACGCCCA-3 & R;5-GCAGGGAATGTAGGTCTGG-3 \\
\hline $\begin{array}{l}\text { NMDA } \\
\text { (Glutamate Receptor) }\end{array}$ & F;5-ACTCCACACTGCCCATGAAC-3 & R;5-TTGTTCCCCAAGAGTTTGCTT-3 \\
\hline FOXP3 & F;5-TCATCCGCTGGGCCATCCTG-3 & R;5-GTGGAAACCTCACTTCTTGGTC-3 \\
\hline CTLA4 & F;5-GGACGCAGATTTATGTCATTGATC-3 & R;5-CCAAGCTAACTGCGACAAGGA-3 \\
\hline GAPDH & F;5-GTGAAGGTCGGAGTCAACG-3 & R;5-CAATGCCAGCCCCAGCG-3 \\
\hline
\end{tabular}

\subsection{Statistical Analysis:}

One-way ANOVA test with Tukey-Kramer method for post-hoc analysis was used to compare data between different groups. Statistical data analysis was performed using SPSS version 22 software (IBM Corp., 2013) with significance set at $P<0.05$. Data were expressed as means \pm standard deviation (M $\pm S . D)$.

\subsection{Ethics Committee Approval:}

All animal procedures were conducted in accordance with the standards set in the guidelines for the care and use of experimental animals by the Animal Ethics Committee of the Zoology Department in the Faculty of Science at Beni-Suef University under approval number BSU/FS/2017/15 at December 15 ${ }^{\text {th }}, 2017$. 


\section{Results}

In comparison to the control group, the pilocarpine-induced epilepsy treatment produced a significant disturbance of electrolytes $(P<0.001$; Table 2$)$ represented by an elevation of sera $\mathrm{Na}^{+}$and $\mathrm{Cl}^{-}(13.89 \pm 0.85$ and $117.53 \pm 10.37 \mathrm{mM} / \mathrm{ml}$, respectively) in contrast to their intracellular decrease in homogenate tissues $(13.89 \pm 0.85$ and $77.17 \pm 4.15 \mathrm{mM} / \mathrm{ml}$, respectively). Treatment with Depakine and $\mathrm{BV}$ returned the elevated levels of $\mathrm{Na}^{+}$and $\mathrm{Cl}^{-}$to normal levels in serum and mitigated their reduction in homogenate tissues: $\mathrm{Na}$ + levels returned to $133.20 \pm 0.69$ and $131.37 \pm 0.57 \mathrm{mM} / \mathrm{ml}$ in the sera of Depakine- and BV-treated groups, respectively; Cl- levels returned to $102.80 \pm 0.44$ and $103.90 \pm 3.28 \mathrm{mM} / \mathrm{ml}$ in the sera of Depakine- and BV-treated groups, respectively.

On the other hand, significant extracellular hypokalemia $(2.95 \pm 0.44 \mathrm{mM} / \mathrm{ml})$ and hypocalcemia $(0.25 \pm 0.03 \mathrm{mM} / \mathrm{ml})$ were recorded in the EP group $(P<0.001)$, as well as significant intracellular hyperkalemia $(130.20 \pm 9.82 \mathrm{mM} / \mathrm{ml})$ and intracellular hypercalcemia $(0.97 \pm 0.12 \mathrm{mM} / \mathrm{ml})(P<0.001$; Table 2$)$. Treatment with Depakine and BV significantly ameliorated the interruption of electrolytes and ions in both the sera and hippocampal tissue $(P<0.001)$.

Biochemical estimation (Fig. 1A-F) of three members of the monoamine catecholamine neurotransmitter family, i.e., I-3,4dihydroxyphenylalanine (DOPA; Fig. 1A), epinephrine (EN; Fig. 1B), and norepinephrine (NEN; Fig. 1C), showed levels that were significantly increased in the hippocampal tissues of the epileptic group $(P<0.001 ; 131.33 \pm 10.00 \mathrm{pg} / \mathrm{mg}$ protein tissue, $209.77 \pm 20.23 \mathrm{pg} / \mathrm{mg}$ protein tissue, and $35.67 \pm 3.23 \mu \mathrm{g} / \mathrm{mg}$ protein tissue, respectively). Additionally, significantly high levels of glutamate $(P<0.001$; Fig. $1 \mathrm{~F})$ were recorded in this group $(20.77 \pm 2.8523 \mathrm{pg} / \mathrm{mg}$ protein tissue). On the other hand, in the pilocarpine-induced epilepticus model, the release of both $y$-aminobutyric acid (GABA; $20.80 \pm 3.24 \mathrm{pg} / \mathrm{mg}$ protein tissue; Fig. 1D) and acetylcholinesterase (AChE; $37.10 \pm 5.71 \mathrm{U} / \mathrm{mg}$ protein tissue; Fig. 1E) were inhibited in comparison with control levels. However, treatment with Depakine and BV significantly stimulated the release of GABA and AChE in hippocampal tissues $(P<0.001)$.

Changes in the relative mRNA expression of some voltage-gated channels are illustrated in Fig. 2A-E. The mRNA levels of channels SCN1A (Na+; Fig. 2A), KCNJ2 (K; Fig.2B), and CLCNC (GABA; Fig. 2D) were significantly reduced after induction of epilepsy relative to control expression levels $(P<0.001 ; 0.23$-fold $\pm 0.03 ; 0.35$-fold \pm 0.03 and 0.15 -fold \pm 0.03 , respectively). In contrast, the mRNA levels of channels CACNCL (Ca ${ }^{+2}$; Fig. 2C) and N-methyl-D-aspartate receptor (NMDAR; Fig. 2E) significantly increased relative to control expression levels $(P<0.001 ; 7.37$-fold \pm 0.40 and 6.17-fold \pm 1.30 , respectively). Treatment with Depakine and BV significantly increased the previously reduced mRNA expression of the SCN1A, KCNJ2, and CLCNC channels $(P<0.001)$, whereas these treatments significantly reduced the previously upregulated expression of the CACNCL and NMDAR channels $(P<0.001)$.

In ELISA evaluations of the antiinflammatory activities of BV (Fig. 3), the venom was found to significantly inhibit all inflammatory biomarkers $(P<0.001)$, including the cytokines IL-6 (61.97 $\pm 3.63 \mathrm{pg} / \mathrm{mg}$ protein tissue), IL-17 (62.67 \pm 6.22 $\mathrm{pg} / \mathrm{mg}$ protein tissue), TNF-a (32.73 $\pm 3.36 \mathrm{pg} / \mathrm{mg}$ protein tissue), and TGF- $\beta$ ( $60.37 \pm 8.60 \mathrm{pg} / \mathrm{mg}$ protein tissue) along with mRNA expression (as fold changes against a control or relative to control) of the T-regulatory nuclear transcription factors FOXP3 (3.11 \pm 0.81$)$ and CTL4 (2.54 \pm 0.61$)$, in hippocampal tissues after induction of epilepsy, which had previously produced a significant elevation of these proinflammatory biomarkers $(P<0.001)$. On the other hand, BV was found to significantly increase antiinflammatory activity by returning levels of IL-10 (197.50 $\pm 5.88 \mathrm{pg} / \mathrm{mg}$ protein tissue) near-control levels (i.e., $217.90 \pm 6.96 \mathrm{pg} / \mathrm{mg}$ protein tissue) after a significant decrease in IL-10 levels in the epilepticus group $(P<0.001$; $99.23 \pm 11.97 \mathrm{pg} / \mathrm{mg}$ protein tissue).

\section{Discussion}

Although, The present study attempted to delineate the effects of BV on the expression of neurotransmitters and imbalance of both electrolytes and inflammatory biomarkers in a pilocarpine-induced epilepticus model. Pilocarpine, as a cholinergic agonist, serves as a model for the acute phase of temporal lobe epilepsy (Clynen et al., 2014). Religious books such as the 
Vedas, Bible, and Quran encourage the use of bee products to treat and cure many human diseases (Silva et al., 2015); thus, this is an ancient treatment that deserves further attention in modern medicine.

The first step in seizure diagnosis is the evaluation of blood chemistry to determine electrolyte abnormalities, especially those involving sodium, calcium, and magnesium (Oguni, 2004). The significant $\mathrm{Na}^{+}, \mathrm{K}^{+}$, and hypocalcemia disorders observed in the present study were in agreement with the findings of Castilla-Guerra et al. (2006), who concluded that major neurological damage may be due to an imbalance in electrolytes and ion gradients across cell membranes, which directly or indirectly affects neuronal discharge and promotes epileptogenesis behavior.

Although acute hypocalcemia recorded in serum can alter mental activity and cause tonic-clonic, focal motor, and atypical absence or kinetic seizures (Riggs, 2002; Mrowka et al., 2004), severe tissue hypercalcemia leads to minimal neurologic symptoms (Marx, 2000). On the other hand, hypokalemia or hyperkalemia rarely cause seizure symptoms. An imbalance in serum potassium levels (extracellular) affects regulation of the neuromuscular and cardiovascular systems, which can cause fatal muscle paralysis or arrhythmias (Riggs, 2002).

Melittin in BV has antinociceptive effects in apipuncture (Son et al., 2007), whereas topical usage of melittin elevates levels of $\mathrm{Ca}^{2+}$ in $69 \%$ of rat dorsal root ganglia in vitro (Chen and Guan, 2017). Melittin-responsive dorsal root ganglia cells have been defined as nociceptors because their action potentials exhibit typical electrophysiological characteristics of nociceptive cells, i.e., long durations and prolonged after-hyperpolarization (Du et al., 2011). Koyama et al. (2000) reported that low doses of melittin ( $5 \mu \mathrm{g}$ in $50 \mu \mathrm{l}$ of saline) gradually inhibit the pain sensation, which disappeared at $3 \mathrm{~min}$. Moreover, melittin increases activity of the $\mathrm{Na}^{+}-\mathrm{K}^{+}$pump by increasing $\mathrm{Na}^{+}$entry into the cell and increases ion flux signals to initiate mitogenesis of quiescent cells (Rozengurt et al., 1981).

The current data suggest that usage of a low therapeutic dose of BV causes hyperpolarization of the presynaptic cells by opening ATP-dependent $\mathrm{K}^{+}$channels, as indicated by increments of channel activity via increased mRNA expression of SCN1A and KCNJ2 channel genes. In addition, voltage-dependent $\mathrm{Ca}^{2+}$ channels were closed, which was indicated by low mRNA expression of voltage-gated $\mathrm{Ca}^{2+}(\mathrm{CACNCL})$ that led to a corresponding reduction in glutamate release (low expression of NMDA receptors) and inhibition of seizures.

The SCN1A channel is a voltage-gated $\mathrm{Na}^{+}$channel found in dendrites and soma. SCN1A plays a critical role during neuronal excitability including the initiation and propagation of action potentials (Lai and Jan, 2006); therefore, the genes of this channel are considered important causative agents in epilepsy (Trimmer and Rhodes, 2004). In addition to Lorincz and Nusser (2010) revealing that dendritic voltage-gated $\mathrm{Na}+$ ( $\mathrm{Nav}$ ) channels support action potentials in cortical pyramidal cells, Seleem (2016) reported that the melittin component of BV could inhibit the activity of Na/K-ATPase. The unequal expression of SCN1A genes that can occur on excitatory pyramidal neurons and inhibitory interneurons may be essential in epileptogenesis (Wei et al., 2017). In the current study, the low expression of voltage-gated potassium in the EP group was in agreement with the work of Lai and Jan (2006), who found that a lack of Kv1, which controls action potential propagation (Lambe and Aghajanian, 2001) and neurotransmitter release (Wang et al., 1994), led to hyperexcitability in the hippocampus and to epilepsy.

The main inhibitory neurotransmitter in the brain, GABA, plays several inhibitory roles during many immune reactions. Therefore, GABAergic medications are used to treat epilepsy, alcohol withdrawal, and anxiety (Bhat et al., 2010). Several drugs, including alcohol and benzodiazepines, cause increased GABA activity, which is associated with a sedative effect. Some potent peptides of natural venoms can mimic such interactions, specifically with ion channels, e.g., $\mathrm{Na}^{+}, \mathrm{K}^{+}, \mathrm{Cl}^{-}$, and $\mathrm{Ca}^{2+}$; therefore, GABAergic neurotransmission can be modulated (Monge-Fuentes et al., 2015). GABA treatment decreases inflammatory cytokine production in peripheral macrophages (Reyes-García et al., 2007). In addition, agonists of GABA and GABA type A receptor decrease cytotoxic immune responses and cutaneous delayed-type hypersensitivity reactions (Tian et al., 1999). 
The interruption in electrolytes and ions, e.g., sodium, potassium, and calcium ions, through voltage- and ligand-gated ion channels causes hyperexcitability (i.e., firing and bursting) of brain neurons. Therefore, voltage-gated $\mathrm{Ca}^{2+} / \mathrm{K}^{+}$channels play a vital role in numerous biological processes such as stimulation of neurotransmitters, muscle contraction, gene expression control, and neuronal migration. Various chemical compounds that influence and modulate the $\mathrm{Ca}^{2+} / \mathrm{K}^{+}$channels are used to treat a variety of neurological disorders (Miller, 2001).

During the propagation of action potentials, the active channels of dendrites function in the physiological, pathophysiological, and electrical behaviors of each neuron. Magee and Johnston (1995) suggested that the density of Ca ${ }^{2+}$ channels is equally distributed in all CAl pyramidal neurons (excluding axonic and terminal regions). $\mathrm{Ca}^{2+}$ channels and the $\mathrm{Ca}^{2+}$ spikes of dendrites aid in the initiation and propagation of somatic bursting behavior and ultimately prolong epileptogenesis (Traub et al., 1993). The influx of $\mathrm{Ca}^{2+}$ into dendrites can be directly increased via voltage-gated dendritic channels when voltage-gated $\mathrm{Ca}^{2+}$ channels are opened or indirectly when NMDA channels are unblocked after depolarization of the postsynaptic membrane (Faber and Sah, 2007; Luján et al., 2009).

Activation of potassium $\mathrm{SK} / \mathrm{K}_{\mathrm{Ca} 2}$ channels may reduce neuronal excitability and delay the development of neuroinflammation. Any increment in submicromolar concentrations of calcium can activate $\mathrm{SK} / \mathrm{K}_{\mathrm{Ca} 2}$ channels in neuronal cells (Dolga and Culmsee, 2012). Apamin can reduce the neurotoxicity of activated microglia as it has high affinity for $\mathrm{SK}_{2} / \mathrm{K}_{\mathrm{Ca} 2.2}$ and $\mathrm{SK}_{3} / \mathrm{K}_{\mathrm{Ca} 2.3}$ channels and can block both (Dolga and Culmsee, 2012).

Data from the present study showed that BV can limit neuronal excitability by rapid repolarization of action potentials as a result of the high rate of outward $\mathrm{K}^{+}$currents through $\mathrm{K}^{+}$channels (Syrbe et al., 2015). This can be achieved by apamin, which contributes to synaptic plasticity by selectively inhibiting and blocking SK channels (a subfamily of $\mathrm{Ca}^{2+}$-activated $\mathrm{K}^{+}$ channels) in the brain and spinal cord; therefore, apamin can potentiate and enhance both learning and memory in experimental animals (Faber and Sah, 2007). Apamin blocks calcium-activated K+ channels by binding to the pores of the SK channels (it acts as an allosteric inhibitor); thus, it lowers the threshold of action potentials, affects the permeability of the cell membrane toward potassium ions, and suppresses delayed cell hyperpolarization (Wehbe et al., 2019; Gu et al., 2020).

An imbalance of $\mathrm{Ca}^{2+}$ ions directly affects the severity of a seizure. This may be due to overexpression of S100B (a calciumbinding astrocytic protein), which causes hyperactivity and impairs hippocampal activity (Winocur et al., 2001). Melittin is known to interact with $\mathrm{S} 100 \mathrm{~B}$, leading to its conformational changes, distortion, and the inaccessibility of its calcium-binding domain, which ultimately decreases epileptogenesis (Verma et al., 2013).

In the present study, a rebalanced state in $\mathrm{Cl}^{-}$levels was observed in sera and tissues after treatment with BV. The redistribution of chloride ions facilitated activation of GABA receptors, which in turn affected membrane conductance dependent upon the anion transporter, which controls the distribution of $\mathrm{Cl}^{-}$and $\mathrm{HCO}^{3-}$ ions (Farrant and Kaila, 2007).

Increasing intracellular calcium concentrations promotes a conformational rotation of $S K / \mathrm{K}_{\mathrm{Ca} 2}$ channels that allows potassium to flow through the channel pore (Adelman et al., 2012). The imbalance of $\mathrm{Ca}^{2+}$ in the hippocampus homogenate tissue may have been due to hyperpolarization after the opening of SK/K $\mathrm{K}_{\mathrm{Ca} 2}$ channels (Stocker, 2004). Moreover, high levels of intracellular calcium may be due to the effects of $\mathrm{SK} / \mathrm{K}_{\mathrm{Ca}} 2$ channels in excitable cells, which are activated by $\mathrm{Ca}^{2+}$ influx from the extracellular space through both ionotropic receptors (e.g., NMDARs) and nicotinic acetylcholine receptors (Dolga and Culmsee, 2012). Vezzani et al. (2011) suggested that high levels of proinflammatory cytokines, neurons, and glia caused signaling activation and rapid increase in NMDA receptor $\mathrm{Ca}^{+2}$, which led to an increase in intracellular $\mathrm{Ca}^{+2}$ levels that in turn reduced the seizure threshold and increased neuronal hyperexcitability and/or reorganized the entire signal network. NMDAR genes (e.g., N-methyl-D-aspartate receptor) play important roles in excitatory synaptic transmission, plasticity, and central nervous system excitation (Wei et al., 2017). In the current study, such channel activity was activated in the epileptic group. 
One aim of research such as this is the reduction of disease progression as well as the side effects of AEDs. Therefore, the high levels of inflammatory cytokines induced by epileptogenic pilocarpine during the present study were in accordance with the findings of previous studies, e.g., De Simoni et al. (2000). Other studies have demonstrated the role of TGF- $\beta$ signaling in glia and local inflammation of the cerebral cortex microenvironment following local blood-brain barrier breakdown, which activates a TGF- $\beta$ receptor-mediated signaling cascade in glia and causes local inflammation (Cacheaux et al., 2009; Vezzani et al., 2013). Therefore, BV treatment may reduce TGF- $\beta$ within activated neurons, resulting in delayed propagation of epileptic activities.

The improvement in inflammatory cytokines, e.g., IL-6, TNF- $\alpha$, TGF- $\beta$, and IL-17, observed here may have been due to the suppressive effect of BV acupuncture on leukocyte migration (Kwon et al., 2003). Recently, Shin et al. (2018) reported that Th1 cytokine, INF-y production, and mucin-producing cells were suppressed by BV. Apamin (contained in BV) is known to inhibit the overexpression of TNF-a and adhesion molecules (e.g., vascular cell adhesion molecule-1, intracellular adhesion molecule-1, fibronectin, and TGF- $\beta 1$ ), and to inhibit cellular apoptosis via inhibition of the NF-KB signaling pathway (Gu et al., 2020). Many biological activities of microglial cells, such as calcium deregulation and cytokine release, can be modulated through $\mathrm{SK}_{3} / \mathrm{K}_{\mathrm{Ca} 2.3}$ (which is one of the potassium channels in microglia). Notably, apamin can suppress the release of

$\mathrm{TNFa}$, which is produced in $\mathrm{SK}_{2} / \mathrm{K}_{\mathrm{Ca} 2.2}$ channel-activated microglia and cortical neurons (Park et al., 2020). Moreover, apamin downregulates inflammation by inhibiting nitric oxide release and decreasing the activity of MAPK (p38-mitogen-activated protein kinase) in activated microglia cells (Schlichter et al., 2010).

In addition to PLA2, as an active component of BV, modulating Treg cells in some neuroinflammatory disease models, including Alzheimer disease (Baek et al., 2018) and Parkinson's disease (Chung et al., 2012) models and therefore BV can rescue dopaminergic neurons from injury or neurodegeneration, melittin can modify the release and production of different cytokines; it was found to increase levels of the antiinflammatory cytokine IL-10 and prevent the release of the proinflammatory cytokines IL-6 and IL-1 $\beta$ (Kim et al., 2020). In addition, BV restores the brain's neurochemistry and ameliorates all changes in neuroinflammatory biomarkers in rotenone-induced Parkinson's disease (Khalil et al., 2015). The components of BV improve locomotor activity by repressing cellular DNA damage via inhibition of many apoptotic markers, e.g., caspase-3, Bax, and Bcl-2, during development of atherosclerotic lesions (Kim et al., 2012; Abd El-Hameed and Mahmoud, 2020) or in Parkinson's disease model mice (Wehbe et al., 2019). Moreover, apamin can ameliorate TNF-a- and IFN- - -induced inflammatory conditions by inhibiting Th2-related cytokines (Kim et al., 2017).

Where IL-17 enhances the release of many cytokines via NF-KB activation (Cipollini et al., 2019), high levels of IL-17 were recorded in the current study and this is a signature cytokine of Th17 cells and its potential function in several brain diseases has been acknowledged (Engelhardt and Ransohoff, 2012). Based on the present results, the injection of melittin in low doses could induce antiinflammatory effects by downregulating IL-6, IL-8, IL-17, TNF-a, and IFN- $\gamma$ through inhibition of various signaling pathways via NF-KB, Akt (protein kinase), and ERK1/2 (extracellular signal-regulated kinases) (Stuhlmeier, 2007; Lee and Bae, 2016; Hossen et al., 2017; Wehbe et al., 2019).

Taken together, the present results and those from earlier studies suggest that BV has multiple antiinflammatory properties, which are largely due to inhibition of proinflammatory cytokine activation. Therefore, BV treatment can serve as a therapeutic approach to reducing the progression of epileptogenesis in combination with AED therapy.

\section{Declarations}

\section{Conflict of interest \& Disclosure Statement:}

All authors declare that they have no conflict of interest with any groups and didn't receive any fund to cover the present study.

2. Data availability statement: all results, tables and figures are attached at the end of the present manuscript 


\section{Author Contributions:}

Conceptualization: Abulesaad, A.S. and Khalil, A.

Data curation: Abulesaad, A.S. and Abd El-Hameed, A.M.

Formal analysis and Investigation: Abulesaad, A.S. and Abd El-Hameed, A.M.

Resources: Abulesaad, A.S; Abd El-Hameed, A.M. and Khalil, A.

Supervision and Validation: Abulesaad, A.S; Abd El-Hameed, A.M. and Khalil, A.

Writing: original draft, review \& final editing: Abulesaad, A.S; Abd El-Hameed, A.M. and Khalil, A.

\section{References}

Abd El-Hameed, A. M.; Eskandrani, A. A.; Elroby, F. A. (2020): Assessment of the ameliorative effect of Hypericum perforatum on olanzapine-induced hepatic oxidative stress and metabolic abnormalities in experimental male albino rats. Journal of Taibah University for Science, v. 14, n. 1, p. 1496-1502, ISSN 1658-3655.

Abd El-Hameed, A. M.; Mahmoud, H. S. (2020): Cypermethrin induced apoptosis and testicular toxicity by upregulation of p53 in the brain and testis of male rats is alleviated by Sesame oil. Journal of Taibah University for Science, v. 14, n. 1, p. 13421349, ISSN 1658-3655.

Abdel-Reheim, E. S. (2009): Physiological and biochemical studies on the melatonin effect on the fertility of epileptic rats. J. Egyp. Ger. Soci. Zool, v. 58, p. 1-25,

Adelman, J. P.; Maylie, J.; Sah, P. (2012): Small-conductance Ca2+-activated K+ channels: form and function. Annual review of physiology, v. 74, p. 245-269, ISSN 0066-4278.

Aust, W.; Wichmann, G.; Dietz, A. (2010): Therapy control of specific hymenoptera venom allergy. Laryngo-rhino-otologie, v. 89, n. 12, p. 725-728, ISSN 0935-8943.

Baek, H.; Lee, C.j.; Choi, D. B.; Kim, N.-s.; Kim, Y.-S.; Ye, Y. J. et al. (2018): Bee venom phospholipase A2 ameliorates Alzheimer's disease pathology in $A \beta$ vaccination treatment without inducing neuro-inflammation in a 3xTg-AD mouse model. SClentIfIC RepoRtS, v. 8, n. 1, p. 1-11, ISSN 2045-2322.

Beghi, E.; Giussani, G.; Nichols, E.; Abd-Allah, F.; Abdela, J.; Abdelalim, A. et al. (2019): Global, regional, and national burden of epilepsy, 1990-2016: a systematic analysis for the Global Burden of Disease Study 2016. The Lancet Neurology, v. 18, n. 4, p. 357-375, ISSN 1474-4422.

Bhat, R.; Axtell, R.; Mitra, A.; Miranda, M.; Lock, C.; Tsien, R. W. et al. (2010): Inhibitory role for GABA in autoimmune inflammation. Proceedings of the National Academy of Sciences, v. 107, n. 6, p. 2580-2585, Disponível em: < https://www.pnas.org/content/pnas/107/6/2580.full.pdf >.

Bradford, M. M. (1976): A rapid and sensitive method for the quantitation of microgram quantities of protein utilizing the principle of protein-dye binding. Analytical biochemistry, v. 72, n. 1-2, p. 248-254, ISSN 0003-2697.

Cacheaux, L. P.; Ivens, S.; David, Y.; Lakhter, A. J.; Bar-Klein, G.; Shapira, M. et al. (2009): Transcriptome profiling reveals TGF- $\beta$ signaling involvement in epileptogenesis. Journal of Neuroscience, v. 29, n. 28, p. 8927-8935, ISSN 0270-6474.

Castilla-Guerra, L.; Fernández-Moreno, M. d. C.; López-Chozas, J. M.; Fernández-Bolaños, R. (2006): Electrolytes disturbances and seizures. Epilepsia, v. 47, n. 12, p. 1990-1998, ISSN 0013-9580.

Page 10/19 
Chen, J.; Guan, S.-M. (2017): Bee Venom and Pain, . Toxins and Drug Discovery, Toxinology v. P. Gopalakrishnakone et al. (eds.), p. 253-295. DOI 10.1007/978-94-007-6452-1_1,

Chung, E. S.; Kim, H.; Lee, G.; Park, S.; Kim, H.; Bae, H. (2012): Neuro-protective effects of bee venom by suppression of neuroinflammatory responses in a mouse model of Parkinson's disease: role of regulatory $T$ cells. Brain, behavior, and immunity, v. 26, n. 8, p. 1322-1330, ISSN 0889-1591.

Cipollini, V.; Anrather, J.; Orzi, F.; ladecola, C. (2019): Th17 and Cognitive Impairment: Possible Mechanisms of Action. Frontiers in Neuroanatomy, v. 13, n. 95, ISSN 1662-5129. Disponível em: < https://www.frontiersin.org/article/10.3389/fnana.2019.00095 >.

Clynen, E.; Swijsen, A.; Raijmakers, M.; Hoogland, G.; Rigo, J.-M. (2014): Neuropeptides as targets for the development of anticonvulsant drugs. Molecular neurobiology, v. 50, n. 2, p. 626-646, ISSN 0893-7648.

Cruciani, R. A.; Barker, J. L.; Zasloff, M.; Chen, H.-C.; Colamonici, O. (1991): Antibiotic magainins exert cytolytic activity against transformed cell lines through channel formation. Proceedings of the National Academy of Sciences, v. 88, n. 9, p. 3792-3796, ISSN 0027-8424.

De Simoni, M. G.; Perego, C.; Ravizza, T.; Moneta, D.; Conti, M.; Marchesi, F. et al. (2000): Inflammatory cytokines and related genes are induced in the rat hippocampus by limbic status epilepticus. European Journal of Neuroscience, v. 12, n. 7, p. 26232633, ISSN 0953-816X.

Dolga, A. M.; Culmsee, C. (2012): Protective roles for potassium SK/KCa2 channels in microglia and neurons. Frontiers in Pharmacology, v. 3, p. 196, ISSN 1663-9812.

Du, Y.-R.; Xiao, Y.; Lu, Z.-M.; Ding, J.; Xie, F.; Fu, H. et al. (2011): Melittin activates TRPV1 receptors in primary nociceptive sensory neurons via the phospholipase A2 cascade pathways. Biochemical and biophysical research communications, v. 408, n. 1, p. 32-37, ISSN 0006-291X.

Engelhardt, B.; Ransohoff, R. M. (2012): Capture, crawl, cross: the T cell code to breach the blood-brain barriers. Trends in immunology, v. 33, n. 12, p. 579-589, ISSN 1471-4906.

Faber, E. L.; Sah, P. (2007): Functions of SK channels in central neurons. Proc. Austral. Physiol. Soc, v. 38, p. 25-34,

Farrant, M.; Kaila, K. (2007): The cellular, molecular and ionic basis of GABAA receptor signalling. Progress in brain research, v. 160 , p. 59-87, ISSN 0079-6123.

Gu, H.; Han, S. M.; Park, K.-K. (2020): Therapeutic effects of apamin as a bee venom component for non-neoplastic disease. Toxins, v. 12, n. 3, p. 195,

Hossen, M. S.; Gan, S. H.; Khalil, M. I. (2017): Melittin, a Potential Natural Toxin of Crude Bee Venom: Probable Future Arsenal in the Treatment of Diabetes Mellitus. Journal of Chemistry, v. 2017, p. 4035626, ISSN 2090-9063. Disponível em: < https://doi.org/10.1155/2017/4035626 >.

Khalil, W. K.; Assaf, N.; ElShebiney, S. A.; Salem, N. A. (2015): Neuroprotective effects of bee venom acupuncture therapy against rotenone-induced oxidative stress and apoptosis. Neurochemistry international, v. 80, p. 79-86, ISSN 0197-0186.

Kim, C. (1997): Potentiating health and the crisis of the immune system. Chapter 24; apitherapy (Bee Venom Therapy)



Kim, H.; Hong, J. Y.; Jeon, W.-J.; Baek, S. H.; Ha, I.-H. (2020): Bee venom melittin protects against cisplatin-induced acute kidney injury in mice via the regulation of M2 macrophage activation. Toxins, v. 12, n. 9, p. 574, 
Kim, S.-J.; Park, J.-H.; Kim, K.-H.; Lee, W.-R.; An, H.-J.; Min, B.-K. et al. (2012): Apamin inhibits THP-1-derived macrophage apoptosis via mitochondria-related apoptotic pathway. Experimental and molecular pathology, v. 93, n. 1, p. 129-134, ISSN 0014-4800.

Kim, W.-H.; An, H.-J.; Kim, J.-Y.; Gwon, M.-G.; Gu, H.; Lee, S.-J. et al. (2017): Apamin inhibits TNF-a-and IFN-y-induced inflammatory cytokines and chemokines via suppressions of NF-KB signaling pathway and STAT in human keratinocytes. Pharmacological Reports, v. 69, n. 5, p. 1030-1035, ISSN 2299-5684.

Kobow, K.; Auvin, S.; Jensen, F.; Löscher, W.; Mody, I.; Potschka, H. et al. (2012): Finding a better drug for epilepsy: antiepileptogenesis targets. Epilepsia, v. 53, n. 11, p. 1868-1876, ISSN 0013-9580.

Koyama, N.; Hirata, K.; Hori, K.; Dan, K.; Yokota, T. (2000): Computer-assisted infrared thermographic study of axon reflex induced by intradermal melittin. PAIN®, v. 84, n. 2-3, p. 133-139, ISSN 0304-3959.

Krell, R. (1996): Value-added products from beekeeping. Food \& Agriculture Org., ISBN 9251038198.

Krishna, M.; Ewan, P.; Diwakar, L.; Durham, S.; Frew, A.; Leech, S. et al. (2011): Diagnosis and management of hymenoptera venom allergy: British Society for Allergy and Clinical Immunology (BSACl) guidelines. Clinical \& Experimental Allergy, v. 41, n. 9, p. 1201-1220, ISSN 0954-7894.

Kwon, Y. B.; Kim, H. W.; Ham, T. W.; Yoon, S. Y.; Roh, D. H.; Han, H. J. et al. (2003): The anti-inflammatory effect of bee venom stimulation in a mouse air pouch model is mediated by adrenal medullary activity. Journal of neuroendocrinology, v. $15, n$. 1 , p. 93-96, ISSN 0953-8194.

Lai, H. C.; Jan, L. Y. (2006): The distribution and targeting of neuronal voltage-gated ion channels. Nature Reviews Neuroscience, v. 7, n. 7, p. 548-562, ISSN 1471-0048. Disponível em: < https://doi.org/10.1038/nrn1938 >.

Lambe, E. K.; Aghajanian, G. K. (2001): The role of Kv1. 2-containing potassium channels in serotonin-induced glutamate release from thalamocortical terminals in rat frontal cortex. Journal of Neuroscience, v. 21, n. 24, p. 9955-9963, ISSN 02706474.

Lee, G.; Bae, H. (2016): Anti-inflammatory applications of melittin, a major component of bee venom: Detailed mechanism of action and adverse effects. Molecules, v. 21, n. 5, p. 616,

Lorincz, A.; Nusser, Z. (2010): Molecular Identity of Dendritic Voltage-Gated Sodium Channels. Science, v. 328, n. 5980, p. 906909, Disponível em: < https://science.sciencemag.org/content/sci/328/5980/906.full.pdf >.

Löscher, W.; Brandt, C. (2010): Prevention or modification of epileptogenesis after brain insults: experimental approaches and translational research. Pharmacological reviews, v. 62, n. 4, p. 668-700, ISSN 0031-6997.

Luján, R.; Maylie, J.; Adelman, J. P. (2009): New sites of action for GIRK and SK channels. Nature Reviews Neuroscience, v. 10, n. 7, p. 475-480, ISSN 1471-0048.

Magee, J. C.; Johnston, D. (1995): Characterization of single voltage-gated Na+ and Ca2+ channels in apical dendrites of rat CA1 pyramidal neurons. The Journal of physiology, v. 487, n. 1, p. 67-90, ISSN 0022-3751.

Marx, S. J. (2000): Hyperparathyroid and hypoparathyroid disorders. New England Journal of Medicine v. 343, p. 18631875 ,

Miller, R. J. (2001): Rocking and rolling with Ca2+ channels. Trends in neurosciences, v. 24, n. 8, p. 445-449, ISSN 0166-2236.

Modzelewska, B.; Kostrzewska, A.; Sipowicz, M.; Kleszczewski, T.; Batra, S. (2003): Apamin inhibits NO-induced relaxation of the spontaneous contractile activity of the myometrium from non-pregnant women. Reproductive Biology and Endocrinology,

Page $12 / 19$ 
v. 1, n. 1, p. 8, ISSN 1477-7827.

Monge-Fuentes, V.; Gomes, F. M. M.; Campos, G. A. A.; de Castro Silva, J.; Biolchi, A. M.; dos Anjos, L. C. et al. (2015): Neuroactive compounds obtained from arthropod venoms as new therapeutic platforms for the treatment of neurological disorders. Journal of Venomous Animals and Toxins including Tropical Diseases, v. 21, n. 1, p. 1-9, ISSN 1678-9199.

Mrowka, M.; Knabe, S.; Klinge, H.; Oden, P.; Rosenow, F. (2004): Hypocalcemic generalized seizures as manifestation of iatrogenic hypoparathyroidism months to years after thyroid surgery. . Epileptic Disorders, v. 6, p. 85-87,

Nair, X.; Nettleton, D.; Clever, D.; Tramposch, K.; Ghosh, S.; Franson, R. (1993): Swine as a model of skin inflammation. Inflammation, v. 17, n. 2, p. 205-215, ISSN 0360-3997.

Nawaz, A.; Khan, M. A.; Naz, R.; Zeb, S. (2019): Extraction of venom from honey bee in district swat, Khyber Pakhtunkhwa, Pakistan. International Journal of Zoology Studies, v. 4, n. 6, p. 27-30. www.zoologyjournals.com,

NCBI. (2020): Standardized bee venom preparation. PubChem Patent Summary for US-8691283-B2,_: National Center for Biotechnology Information. . Retrieved December 31, 2020

Newton, C. R.; Garcia, H. H. (2012): Epilepsy in poor regions of the world. The Lancet, v. 380, n. 9848, p. 1193-1201, ISSN 0140-6736.

Oguni, H. (2004): Diagnosis and treatment of epilepsy. Epilepsia, v. 45, p. 13-16, ISSN 0013-9580.

Park, J.; Jang, K. M.; Park, K.-K. (2020): Apamin suppresses LPS-induced neuroinflammatory responses by regulating SK CHANNELS and TLR4-mediated signaling pathways. International journal of molecular sciences, v. 21, n. 12, p. 4319,

Park, K. M.; Kim, S. E.; Lee, B. I. (2019): Antiepileptic drug therapy in patients with drug-resistant epilepsy. Journal of Epilepsy Research, v. 9, n. 1, p. 14,

Reyes-García, M. G.; Hernández-Hernández, F.; Hernández-Téllez, B.; García-Tamayo, F. (2007): GABA (A) receptor subunits RNA expression in mice peritoneal macrophages modulate their IL-6/IL-12 production. Journal of neuroimmunology, v. $188, n$. 1-2, p. 64-68, ISSN 0165-5728.

Riggs, J. E. (2002): Neurologic manifestations of electrolyte disturbances. Neurologic clinics, v. 20, n. 1, p. 227-239, ISSN 0733-8619.

Rozengurt, E.; Gelehrte, T. D.; Legg, A.; Pettican, P. (1981): Melittin stimulates Na entry, Na-K pump activity and DNA synthesis in quiescent cultures of mouse cells. Cell v. 23, n. (3), p. 781-788. doi: 10.1016/0092-8674(81)90442-6.,

Schlichter, L. C.; Kaushal, V.; Moxon-Emre, I.; Sivagnanam, V.; Vincent, C. (2010): The Ca 2+ activated SK3 channel is expressed in microglia in the rat striatum and contributes to microglia-mediated neurotoxicity in vitro. Journal of neuroinflammation, v. 7, n. 1, p. 1-15, ISSN 1742-2094.

Seleem, A. A. (2016): The protective effect of bee venom against verapamil embryotoxicity during prenatal liver and kidney development of mice Mus musculus. The Journal of Basic \& Applied Zoology, v. 75, p. 13-27, ISSN 2090-9896.

Shin, M., Cheolsu; McNamara, M., James O. (1994): Mechanism of epilepsy. Annual review of medicine, v. 45, n. 1, p. 379-389, ISSN 0066-4219.

Shin, S. H.; Ye, M. K.; Choi, S. Y.; Park, K. K. (2018): Anti-inflammatory effect of bee venom in an allergic chronic rhinosinusitis mouse model. Molecular medicine reports, v. 17, n. 5, p. 6632-6638, ISSN 1791-2997. 
Silva, J.; Monge-Fuentes, V.; Gomes, F.; Lopes, K.; Anjos, L. D.; Campos, G. et al. (2015): Pharmacological alternatives for the treatment of neurodegenerative disorders: Wasp and bee venoms and their components as new neuroactive tools. Toxins, $v$. 7, n. 8, p. 3179-3209,

Son, D. J.; Lee, J. W.; Lee, Y. H.; Song, H. S.; Lee, C. K.; Hong, J. T. (2007): Therapeutic application of anti-arthritis, painreleasing, and anti-cancer effects of bee venom and its constituent compounds. Pharmacology \& therapeutics, v. 115, n. 2, p. 246-270, ISSN 0163-7258.

Stocker, M. (2004): Ca 2+-activated K+ channels: molecular determinants and function of the SK family. Nature Reviews Neuroscience, v. 5, n. 10, p. 758-770, ISSN 1471-0048.

Stuhlmeier, K. M. (2007): Apis mellifera venom and melittin block neither NF-kB-p50-DNA interactions nor the activation of $\mathrm{NF}-\mathrm{KB}$, instead they activate the transcription of proinflammatory genes and the release of reactive oxygen intermediates. The Journal of Immunology, v. 179, n. 1, p. 655-664, ISSN 0022-1767.

Syrbe, S.; Hedrich, U. B.; Riesch, E.; Djémié, T.; Müller, S.; Møller, R. S. et al. (2015): De novo loss-or gain-of-function mutations in KCNA2 cause epileptic encephalopathy. Nature genetics, v. 47, n. 4, p. 393-399, ISSN 1546-1718.

Tian, J.; Chau, C.; Hales, T. G.; Kaufman, D. L. (1999): GABAA receptors mediate inhibition of T cell responses. Journal of neuroimmunology, v. 96, n. 1, p. 21-28, ISSN 0165-5728.

Traub, R. D.; Miles, R.; Jefferys, J. (1993): Synaptic and intrinsic conductances shape picrotoxin-induced synchronized afterdischarges in the guinea-pig hippocampal slice. The Journal of Physiology, v. 461, n. 1, p. 525-547, ISSN 0022-3751.

Trimmer, J. S.; Rhodes, K. J. (2004): Localization of voltage-gated ion channels in mammalian brain. Annu. Rev. Physiol., v. 66, p. 477-519, ISSN 0066-4278.

Trumbeckaite, S.; Dauksiene, J.; Bernatoniene, J.; Janulis, V. (2015): Knowledge, attitudes, and usage of apitherapy for disease prevention and treatment among undergraduate pharmacy students in Lithuania. Evidence-Based Complementary and Alternative Medicine, v. 2015, ISSN 1741-427X.

Turski, L.; Ikonomidou, C.; Turski, W. A.; Bortolotto, Z. A.; Cavalheiro, E. A. (1989): Cholinergic mechanisms and epileptogenesis. The seizures induced by pilocarpine: a novel experimental model of intractable epilepsy. Synapse, v. 3, n. 2, p. 154-171, ISSN 0887-4476.

Verma, N.; Karmakar, M.; Singh, K.; Smita, S. (2013): Structural and dynamic insights into S100B protein activity inhibition by melittin for the treatment of epilepsy. Int. J. Comp. App. NSAAILS, v. 1, p. 55-60,

Vezzani, A.; French, J.; Bartfai, T.; Baram, T. Z. (2011): The role of inflammation in epilepsy. Nature reviews neurology, v. 7, n. 1, p. 31, ISSN 1759-4766.

Vezzani, A.; Friedman, A.; Dingledine, R. J. (2013): The role of inflammation in epileptogenesis. Neuropharmacology, v. 69, p. 16-24, ISSN 0028-3908.

Wang, H.; Kunkel, D.; Schwartzkroin, P. A.; Tempel, B. L. (1994): Localization of Kv1. 1 and Kv1. 2, two K channel proteins, to synaptic terminals, somata, and dendrites in the mouse brain. Journal of Neuroscience, v. 14, n. 8, p. 4588-4599, ISSN 02706474.

Wehbe, R.; Frangieh, J.; Rima, M.; El Obeid, D.; Sabatier, J.-M.; Fajloun, Z. (2019): Bee venom: Overview of main compounds and bioactivities for therapeutic interests. Molecules, v. 24, n. 16, p. 2997,

Wei, F.; Yan, L.-M.; Su, T.; He, N.; Lin, Z.-J.; Wang, J. et al. (2017): Ion channel genes and epilepsy: functional alteration, pathogenic potential, and mechanism of epilepsy. Neuroscience bulletin, v. 33, n. 4, p. 455-477, ISSN 1673-7067.

Page 14/19 
WHO. (2020): https://www.who.int/health-topics/epilepsy\#tab=tab_1. 2020.

Winocur, G.; Roder, J.; Lobaugh, N. (2001): Learning and memory in S100- $\beta$ transgenic mice: an analysis of impaired and preserved function. Neurobiology of learning and memory, v. 75, n. 2, p. 230-243, ISSN 1074-7427.

\section{Table}

Table (2): Changes in electrolytes in sera and brain tissues of control (C), epileptic group (EP), Depakine ${ }^{\circledR}$ treated group (EP_DK), and bee venom-treated group (EP_BV). Values were represented as Mean \pm $\mathrm{SD} \& \mathrm{n}=8$ animals. Means within same parameter and not sharing a common superscript symbol(s), are differ significantly at $\mathrm{P}<0.05$.

\begin{tabular}{|c|c|c|c|c|c|c|c|c|}
\hline & \multicolumn{2}{|c|}{$\mathrm{Na}^{+}$} & \multicolumn{2}{c|}{$\mathrm{K}^{+}$} & \multicolumn{2}{c|}{$\mathrm{Ca}^{2+}$} & \multicolumn{2}{c|}{$\mathrm{Cl}^{-}$} \\
\cline { 2 - 9 } & Serum (mM/ml) & $\begin{array}{c}\text { Tissues } \\
(\mathrm{mM} / \mathrm{ml})\end{array}$ & Serum (mM/ml) & $\begin{array}{c}\text { Tissues } \\
(\mathrm{mM} / \mathrm{ml})\end{array}$ & Serum $(\mathrm{mM} / \mathrm{ml})$ & $\begin{array}{c}\text { Tissues } \\
(\mathrm{mM} / \mathrm{ml})\end{array}$ & Serum (mM/ml) & $\begin{array}{c}\text { Tissues } \\
(\mathrm{mM} / \mathrm{m})\end{array}$ \\
\hline C & 132.20 & 22.47 & $6.28 \pm 0.66^{\mathrm{c}}$ & 94.17 & 0.47 & 0.33 & 109.20 & 93.70 \\
& $\pm 0.61^{\mathrm{a}}$ & $\pm 0.70^{\mathrm{b}}$ & & $\pm 1.61^{\mathrm{a}}$ & $\pm 0.03^{\mathrm{a}}$ & $\pm 0.08^{\mathrm{a}}$ & $\pm 8.38^{\mathrm{a}}$ & $\pm 3.50^{\mathrm{b}}$ \\
\hline EP & 141.70 & 13.89 & 2.95 & 130.20 & 0.25 & 0.97 & 117.53 & 77.17 \\
& $\pm 1.06^{\mathrm{b}}$ & $\pm 0.85^{\mathrm{a}}$ & $\pm 0.44^{\mathrm{a}}$ & $\pm 9.82^{\mathrm{b}}$ & $\pm 0.03^{\mathrm{b}}$ & $\pm 0.12^{\mathrm{b}}$ & $\pm 10.37^{\mathrm{a}}$ & $\pm 4.15^{\mathrm{a}}$ \\
\hline Ep_DK & 133.20 & 20.23 & 4.49 & 106.50 & 0.49 & 0.29 & 102.80 & 82.83 \\
& $\pm 0.69^{\mathrm{a}}$ & $\pm 1.06^{\mathrm{b}}$ & $\pm 0.08^{\mathrm{ab}}$ & $\pm 6.63^{\mathrm{a}}$ & $\pm 0.02^{\mathrm{a}}$ & $\pm 0.02^{\mathrm{a}}$ & $\pm 0.44^{\mathrm{a}}$ & $\pm 4.92^{\mathrm{a}}$ \\
\hline EP_BV & 131.37 & 21.47 & 5.25 & 90.50 & 0.40 & 0.28 & 103.90 & 95.15 \\
& $\pm 0.57^{\mathrm{a}}$ & $\pm 0.83^{\mathrm{b}}$ & $\pm 1.07^{\mathrm{bc}}$ & $\pm 4.09^{\mathrm{a}}$ & $\pm 0.06^{\mathrm{a}}$ & $\pm 0.04^{\mathrm{a}}$ & $\pm 3.28^{\mathrm{a}}$ & $\pm 2.96^{\mathrm{b}}$ \\
\hline F & 119.622 & 58.769 & 13.238 & 24.139 & 27.111 & 63.819 & 2.876 & 14.426 \\
value & & & & & & & & \\
\hline P< & 0.000 & 0.000 & 0.002 & 0.000 & 0.000 & 0.000 & 0.103 & 0.001 \\
\hline
\end{tabular}

\section{Figures}



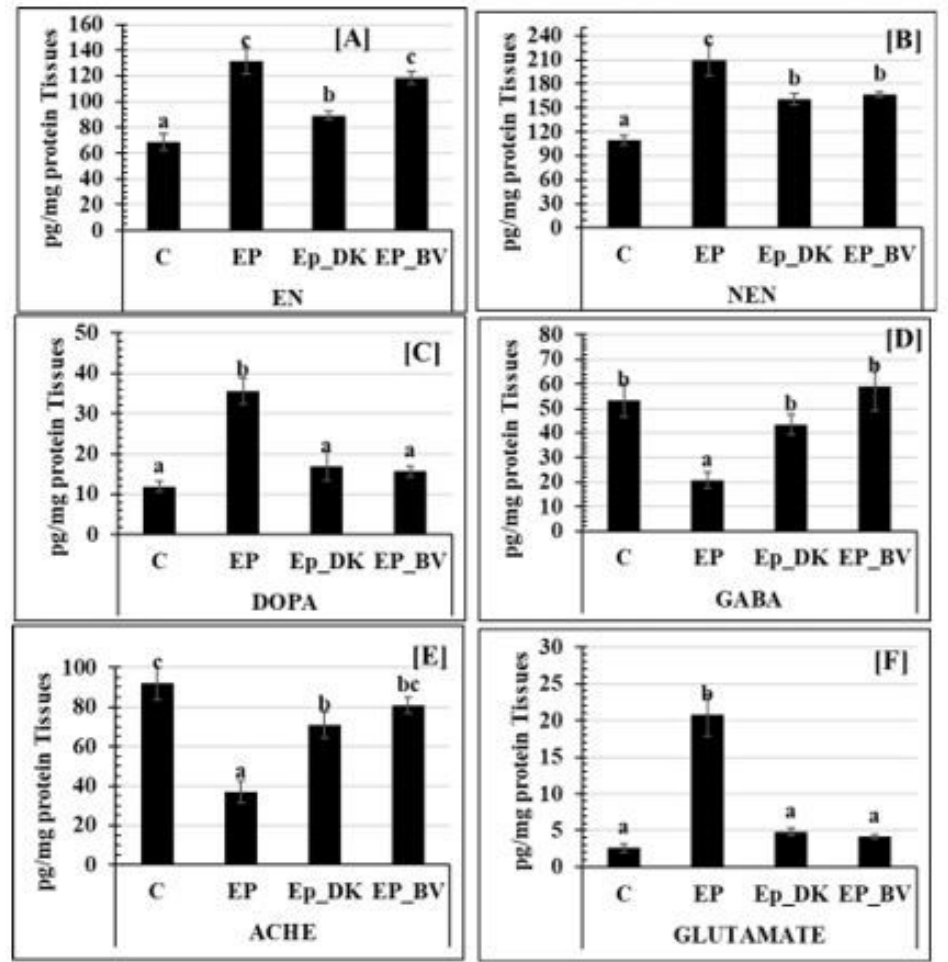

Fig, 1: Biochemical changes in catecholamine neurotransmitter family e.g. DOPA (Fig. IA), epinephrine (EN, Fig.1B) and norepinephrine (NEN, Fig.1C); $\gamma$-aminobutyric acid (GABA, Fig.ID) acetylcholinesterase (AChE, Fig.IE) and glutamate (Fig.IF) in hippocampal tissues control (C), epileptic (EP), DepakineR-treated (EP_DK), and bee venom-treated (EP BV) groups. Values were represented as Mean \pm SD \& $n=8$ animals. Means within same parameter and not sharing a common superscript symbol(s). are differ significantly at $\mathrm{P}<0.05$.

Figure 1

Due to technical limitations, figure caption is only available in the figure. 

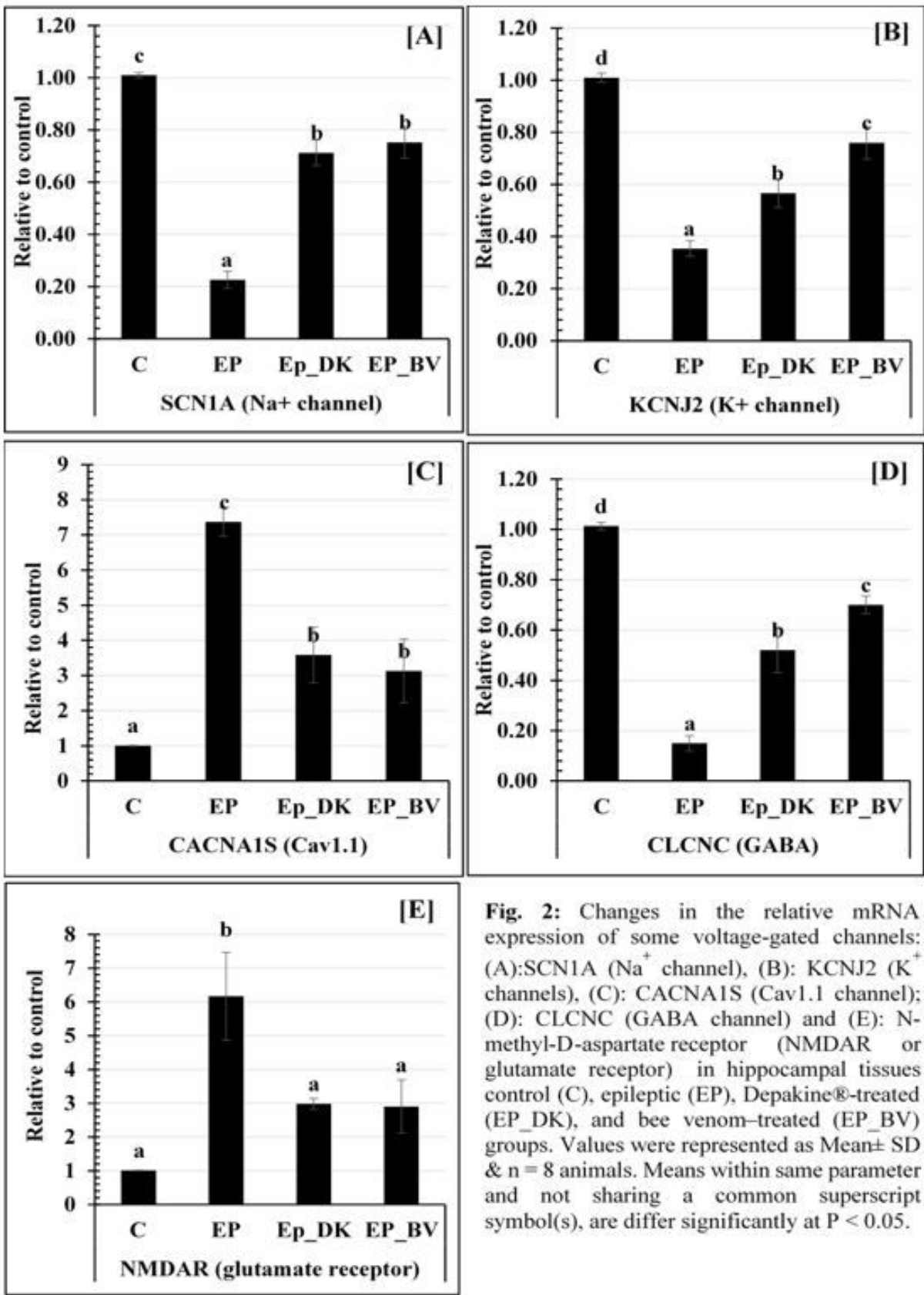

Fig. 2: Changes in the relative mRNA expression of some voltage-gated channels: (A): SCN1A $\left(\mathrm{Na}^{+}\right.$channel), (B): KCNJ2 $\left(\mathrm{K}^{+}\right.$ channels), (C): CACNA1S (Cavl.1 channel); (D): CLCNC (GABA channel) and (E): Nmethyl-D-aspartate receptor (NMDAR or glutamate receptor) in hippocampal tissues control (C), epileptic (EP), Depakine $\mathbb{R}$-treated (EP_DK), and bee venom-treated (EP BV) groups. Values were represented as Mean $\pm \mathrm{SD}$ $\& \mathrm{n}=8$ animals. Means within same parameter and not sharing a common superscript symbol(s), are differ significantly at $\mathrm{P}<0.05$.

\section{Figure 2}

Due to technical limitations, figure caption is only available in the figure. 



Fig. 3: Changes in the relative mRNA expression of some nuclear transcrption factors: (A):FOXP3, (B): CTLA4 and ELISA estimation for interleukin-17 (C) in hippocampal tissues of the control (C), epileptic (EP), Depakine $(\mathbb{R}$-treated (EP DK), and bee venom-treated (EP_BV) groups. Values were represented as Mean \pm SD \& $n=$ 8 animals. Means within same parameter and not sharing a common superscript symbol(s), are differ significantly at $\mathrm{P}<0.05$.

Figure 3

Due to technical limitations, figure caption is only available in the figure. 

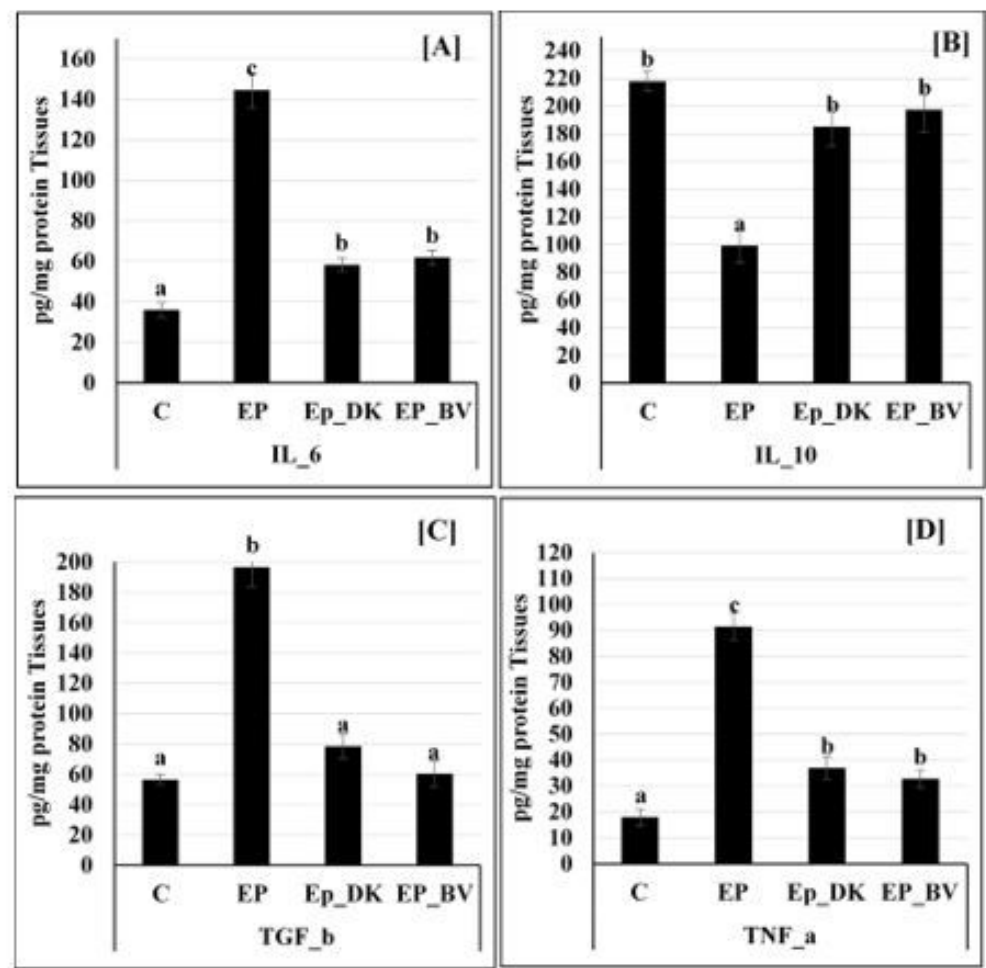

Fig. 4: Changes in levels of cytokines (A): IL -6, (B): IL-10, (C): TGF-b and (D) TNF-a, in hippocampal tissues control (C), epileptic (EP), Depakinek-treated (EP_DK), and bee venom-treated (EP_BV) groups. Values were represented as Meant SD \& $n=8$ animals. Means within same parameter and not sharing a common superscript symbol(s), are differ significantly at $\mathrm{P}<0.05$.

Figure 4

Due to technical limitations, figure caption is only available in the figure. 